\title{
Neospora caninum: High susceptibility to the parasite in $\mathrm{C} 57 \mathrm{BL} / 10 \mathrm{ScCr}$ mice
}

\author{
A.S. Botelho ${ }^{\text {a }}$, L. Teixeira ${ }^{\text {a }}$, J.M. Correia-da-Costa ${ }^{\text {b,c }}$, A.M.R. Faustino ${ }^{\text {a }}$, \\ A.G. Castro ${ }^{\mathrm{d}}$, M. Vilanova ${ }^{\mathrm{a}, \mathrm{e}, *}$ \\ a ICBAS-Instituto de Ciências Biomédicas de Abel Salazar, Largo do Professor Abel Salazar 2, 4099-003, Porto, Portugal \\ ${ }^{\mathrm{b}}$ Centro de Imunologia e Biologia Parasitária, INSA, Porto, Portugal \\ ${ }^{\mathrm{C}}$ CECA-Centro de Estudos de Ciência Animal, Universidade do Porto, Campus Agrário de Vairão, Portugal \\ ${ }^{\mathrm{d}}$ ICVS - Instituto de Investigação em Ciências da Vida e da Saúde e Escola de Ciências da Saúde, Universidade do Minho, Braga, Portugal \\ ${ }^{\mathrm{e}}$ IBMC-Instituto de Biologia Molecular e Celular, Porto, Portugal
}

Received 8 February 2006; received in revised form 26 May 2006; accepted 13 June 2006

Available online 4 August 2006

\begin{abstract}
C57BL/10ScCr mice, lack Toll-like receptor 4 and a functional Interleukin-12 receptor. Taking this into account, susceptibility of these mice to Neospora caninum infection was assessed comparatively to that of immunocompetent C57BL/10ScSn mice. C57BL/10ScCr mice inoculated intraperitoneally with $5 \times 10^{5} \mathrm{~N}$. caninum tachyzoites showed a high susceptibility to this parasite. All infected C57BL/10ScCr mice were dead by day 8 post-infection whereas all control C57BL/10ScSn mice survived this parasitic challenge. Immunohistochemical analysis of infected $\mathrm{C} 57 \mathrm{BL} / 10 \mathrm{ScCr}$ mice showed $N$. caninum tachyzoites spread in the pancreas, liver, lung, intestine, heart and brain whereas no parasites were detected in similarly infected C57BL/10ScSn controls. The higher susceptibility of C57BL/10ScCr mice to neosporosis correlates with reduced interferon- $\gamma$ mRNA expression and increased IL-4 mRNA expression, comparatively to C57BL/10ScSn controls, detected in the spleen after the parasitic challenge. C57BL/10ScCr mice could thus be used as a new experimental model where to study immunobiological mechanisms associated with host susceptibility to neosporosis.
\end{abstract}

(C) 2006 Elsevier Inc. All rights reserved.

Index Descriptors and Abbreviations: Neospora caninum acute infection; Apicomplexa; C57BL/10 ScCr (ScCr) mice; C57BL/10 ScSn (ScSn) mice; NcT, Neospora caninum tachyzoites; IFN- $\gamma$, interferon- $\gamma$; IL-4, interleukin-4; IL-12, interleukin-12; TLR4, Toll-like receptor 4; IL-12R, IL-12 receptor; Th1, T helper 1; PBS, phosphate-buffered saline; RNA, ribonucleic acid; DNA, deoxyribonucleic acid; mRNA, messenger ribonucleic acid; cDNA, RNA to complementary DNA; PCR, polymerase chain reaction; HPRT, hypoxanthine phosphoribosyltransferase; dNTPs, deoxynucleotide triphosphate mix

\section{Introduction}

Neospora caninum is an Apicomplexa protozoan, closely related to Toxoplasma gondii, first identified as the causative agent of a neuromuscular disease in dogs (Bjerkås et al., 1984). Later, $N$. caninum was found to infect a wide range of animal hosts including cattle (Dubey, 2003). Neosporosis is now recognized as a major cause of bovine abortions around the world (Dubey et al., 1988) with an important negative impact in dairy industry (Dubey and

\footnotetext{
* Corresponding author. Fax: +351 222062232.

E-mail address: vilanova@icbas.up.pt (M. Vilanova).
}

Lindsay, 1996). No effective chemotherapeutic agent or vaccine is presently available to treat or prevent satisfactorily neosporosis in cattle (Haddad et al., 2005).

Severe clinical neosporosis can be induced experimentally in immunodeficient mice (Sawada et al., 1997; Nishikawa et al., 2001; Dreier et al., 1999; Lindsay and Dubey, $1989 b)$. Such is the case of interferon- $\gamma$ (IFN- $\gamma$ ) gene knockout mice that are highly susceptible to inoculation with $N$. caninum tachyzoites (Nishikawa et al., 2001). These mice, although considered good animal models to perform bioassays aimed at detecting $N$. caninum, are however often difficult to obtain as previously remarked (Dubey and Lindsay, 2000). 
$\mathrm{C} 57 \mathrm{BL} / 10 \mathrm{ScCr}(\mathrm{ScCr})$ mice are homozygous for a deletion encompassing Tlr4 and therefore fail to express Tolllike receptor 4 (TLR4) (Poltorak et al., 1998; Poltorak et al., 2000). Moreover, these mice also exhibit an impaired responsiveness to interleukin-12 (IL-12) (Merlin et al., 2001). This ScCr mice defect is linked to a point mutation that results in the precocious termination of the transcript for the IL-12R $\beta 2$ chain in the IL-12 receptor (IL-12R) (Poltorak et al., 2001). In contrast, the wild-type C57BL/10 $\mathrm{ScSn}(\mathrm{ScSn})$ mice are TLR4-competent and have no defective IL-12-mediated responses (Poltorak et al., 2000).

The host protective immune response to parasitic invasion, and to N. caninum in particular, is cell mediated and associated to T helper 1 (Th1)-type responses with INF- $\gamma$ and IL-12 having a key role in immune protective mechanisms against infection with this parasite (Innes et al., 2005). Therefore, taking into account the characteristics of the $\mathrm{ScCr}$ strain, in the present report we aimed at evaluating the susceptibility of these mice to $N$. caninum infection.

\section{Materials and methods}

\subsection{Mice}

Male C57BL/10ScSn and $\mathrm{C} 57 \mathrm{BL} / 10 \mathrm{ScCr}$ mice (6-8 weeks old) were obtained from the Gulbenkian Institute of Science (Oeiras, Portugal). Mice were kept at the animal facilities of the Institute Abel Salazar during the experiments. Procedures involving mice were performed according to the European Convention for the Protection of Vertebrate Animals used for Experimental and Other Scientific Purposes (ETS 123) and 86/609/EEC Directive and Portuguese rules (DL 129/92).

\subsection{Neospora caninum}

Neospora caninum tachyzoites (NcT) (NC-1 isolate) were cultured and serially passaged in VERO cells maintained at $37^{\circ} \mathrm{C}$ in Minimum Essential Medium (MEM) containing Earle's salts (Gibco: Invitrogen Corporation, Carlsbad, California) supplemented with $10 \%$ fetal calf serum, L-glutamin $(2 \mathrm{mM})$, penicillin $(200 \mathrm{IU} / \mathrm{ml})$, and streptomycin $(200 \mu \mathrm{g} / \mathrm{ml})$ (all from Sigma, St. Louis, USA) in a humidified atmosphere of $5 \% \mathrm{CO}_{2}$ in air. Free parasitic forms of $N$. caninum were obtained as previously described (Hemphill, 1996) with some modifications. Infected VERO cells were cultured until the host cell monolayer was $90 \%$ destroyed. Culture supernatants and adherent cells, harvested using a cell scraper, were centrifuged at $1100 \mathrm{~g}$ for $10 \mathrm{~min}$. The pellet was then passed through a $25 \mathrm{G}$ needle and then washed three times in phosphate-buffered saline (PBS) (centrifugation at $1100 \mathrm{~g}$ for $10 \mathrm{~min}$ ). The pellet thus obtained was resupended in $3 \mathrm{~mL}$ of PBS and passed through a PD-10 column (Amersham Biosciences Europe $\mathrm{GmbH}$, Freiburg, Germany). Parasite concentration was determined with a hemocytometer.

\subsection{Challenge infections}

Neospora caninum infections were performed by intraperitoneal (i.p.) inoculation of $0.5 \mathrm{ml}$ PBS containing $5 \times 10^{5}$ tachyzoites. Control mice were similarly treated with $0.5 \mathrm{ml}$ PBS.

\subsection{Histopathologic examination and immunohistochemistry}

Brain, heart, intestine, pancreas, lung, and liver from $N$. caninum-infected mice and controls were collected and fixed in $10 \%$ buffered formalin and sections with $3 \mathrm{~mm}$ gap of each organ were obtained. These were dehydrated, embedded in paraffin wax and four serial sections were cut from each block. One section was stained with haematoxylin-eosin and the others were used for immunohistochemistry, performed according to the modified avidin-biotin-peroxidase complex (ABC) method (Hsu et al., 1981). Briefly, sections were dewaxed, rehydrated and immersed in $10 \%$ target retrieval solution (Dako, Carpinteria, CA, USA) and incubated in a water bath at $100^{\circ} \mathrm{C}$ for $20 \mathrm{~min}$. Endogenous peroxidase activity was blocked by treatment with $0.3 \%$ hydrogen peroxide in methanol (Merck, Darmstadt, Germany) for $10 \mathrm{~min}$. Sections were then incubated in a moist chamber for 20 min with normal pig serum (Dako, Glostrup, Denmark) diluted 1:5 in 10\% bovine serum albumin (Sigma), to eliminate non-specific staining. Excess serum was removed and the sections were incubated overnight at $4^{\circ} \mathrm{C}$, with an anti- $N$. caninum rabbit anti-serum (Lindsay and Dubey, 1989a), diluted 1:5000. Subsequently, slides were incubated for $30 \mathrm{~min}$ with a 1:200 dilution of biotinlabelled anti-rabbit secondary antibody (Dako, Glostrup, Denmark) and then with the avidin-biotin-peroxidase complex (Dako, Glostrup, Denmark), for further $30 \mathrm{~min}$. The colour was developed by incubation with diaminobenzidine (Dako, Carpinteria, CA, USA) for $7 \mathrm{~min}$. After counterstaining tissue sections with haematoxylin, slides were mounted in Entellan (Merck). A positive reaction was indicated by the presence of brown cytoplasmic staining and formalin-fixed NcT were used as positive controls. The immunohistochemistry reaction was evaluated in a semi-quantitative mode through the count of all tachyzoites present in 5 fields of high amplification (objective $40 \times$ and ocular $10 \times$ ). The adopted scale for the parasite burden was established in Table 1.

\subsection{RNA isolation and quantitative real-time PCR analysis}

Total RNA was extracted from $1 \times 10^{6}$ spleen mononuclear cells of $\mathrm{ScSn}$ and $\mathrm{ScCr}$ mice of the different experimental groups using TriPure ${ }^{\mathrm{TM}}$ Isolation Reagent (Roche Diagnostics, Indianapolis, IN, USA) according to manufacturer's instructions. All RNA samples were recovered in $50 \mu \mathrm{l}$ of nuclease-free $\mathrm{H}_{2} \mathrm{O}$ and spectrophotometrically analyzed for quantity and quality. Synthesis of cDNA was then performed from $200 \mu \mathrm{g}$ of total RNA prepared as described above in a $20 \mu \mathrm{l}$ final volume using 
Table 1

Semi-quantitative histopathological (HE staining) and immunochemical analysis for the presence of $N$. caninum, in organs of $\mathrm{ScSn}$ and $\mathrm{ScCr}$ mice at day 7 after i.p. infection with $5 \times 10^{5}$ tachyzoites

Tissue types

Mice Mice number Brain Heart Lung Pancreas Intestine Liver

\begin{tabular}{|c|c|c|c|c|c|c|c|}
\hline \multirow[t]{4}{*}{$\mathrm{ScSn}$} & $1^{\mathrm{a}}$ & - & - & - & - & - & - \\
\hline & $2^{\mathrm{a}}$ & - & - & - & - & - & - \\
\hline & $3^{\mathrm{a}}$ & - & - & - & - & - & - \\
\hline & $4^{a}$ & - & - & - & - & - & - \\
\hline \multirow[t]{4}{*}{$\mathrm{ScCr}$} & 1 & - & + & $++^{\mathrm{b}}$ & $++++^{b}$ & $++^{\mathrm{b}}$ & $++++^{b}$ \\
\hline & 2 & + & - & $++^{\mathrm{b}}$ & $++++^{\mathrm{b}}$ & ++ & $++++^{b}$ \\
\hline & 3 & + & + & $++^{\mathrm{b}}$ & $++++^{b}$ & $++{ }^{b}$ & $++++^{b}$ \\
\hline & 4 & + & - & $++^{\mathrm{b}}$ & $++++^{b}$ & $++^{b}$ & $++++^{b}$ \\
\hline
\end{tabular}

- , without tachyzoites;,+ 1 a 10 tachyzoites;,$++ 10-30$ tachyzoites; +++ , 30-50 tachyzoites;,$++++>50$ tachyzoites.

a Mice euthanized 90 days post-infection.

b With associated lesions.

$200 \mathrm{U}$ of Superscript ${ }^{\mathrm{TM}}$ RNAse H Reverse Transcriptase (Invitrogen, Carlsbad, CA, USA) according to manufacturer's instructions. The Polymerase Chain Reaction (PCR) program run $\left(42^{\circ} \mathrm{C}, 60 \mathrm{~min} ; 70^{\circ} \mathrm{C}, 15 \mathrm{~min} ; 4^{\circ} \mathrm{C}\right.$ infinite) was performed in a Bio-Rad iCycler Thermal Cycler (Bio-Rad, Hercules, CA, USA). Real-time PCR was then used for the quantification of hypoxanthine phosphoribosyltransferase (HPRT) or cytokine messenger RNA (mRNA) expression levels with the LightCycler FastStart DNA Master Hybridization Probes kit (Roche, Penzberg, Germany) in a LightCycler device (Roche, Penzberg, Germany). For the quantification of HPRT expression levels, the reaction was performed in a final volume of $10 \mu \mathrm{l}$ containing $5.0 \mathrm{mM} \mathrm{MgCl} 2,1.0 \mu \mathrm{M}$ of each primer (Sense: 5'-GCT GGT GAA AAG GAC CTC T, antisense: 5'-CAC AGG ACT AGA ACA CCT GC), $0.2 \mu \mathrm{M}$ of each probe (3'-fluorescein-labelled [FL] 5'-AAA GCC TAA GAT GAG CGC AAG TTG A-FL, 5'-LCRed 640-labelled [LC] 5'-TCT GCA AAT ACG AGG AGT CCT GTT G-PH), and $1 \times$ Master Mix plus $1 \mu \mathrm{l}$ of the synthesized cDNA. The PCR program run was as follows: (1) denaturation at $95^{\circ} \mathrm{C}, 10 \mathrm{~min}$ (2) amplification in 40 cycles $95^{\circ} \mathrm{C}, 10 \mathrm{~s} ; 60^{\circ} \mathrm{C}, 10 \mathrm{~s} ; 72^{\circ} \mathrm{C}, 11 \mathrm{~s}$ (3) cooling $40^{\circ} \mathrm{C}, 2 \mathrm{~min}$. The temperature transition rate was $20^{\circ} \mathrm{C} / \mathrm{s}$ in all steps. Quantification of IFN- $\gamma$ expression levels was similarly performed with specific primers (sense: 5'-TGG CAA AAG GAT GGT GAC ATG, antisense: 3'-GAC TCC TTT TCC GCT TCC TGA) (TibMol, Berlin, Germany), and probes (FL TGC CAA GTT TGA GGT CAA CAA CCC ACA-FL; LC TCC AGC GCC AAG CAT TCA ATG AGC-PH) (TibMol) in $\mathrm{MgCl}_{2} 4.0 \mathrm{mM}$ and an annealing temperature of $52^{\circ} \mathrm{C}$, and extension at $72^{\circ} \mathrm{C}$, $12 \mathrm{~s}$. At the end of each annealing phase fluorescence was measured in a "single" acquisition mode with the channel setting F2/F1. Quantification of IL-4 expression levels was also similarly performed with specific primers (sense: 5'-AGG TCA CAG GAG AAG GGA CG, antisense: 3'-TGC AGC TTA TCG ATG AAT CCA G) (TibMol, Berlin, Germany), and probes (FL ACC TTG GAA GCC
CTA CAG ACG AGC-FL; LC ACT CTC TGT GGT GTT CTT CGT TGC TGT G-PH) (TibMol) in $\mathrm{MgCl}_{2}$ $4.0 \mathrm{mM}$ and an annealing temperature of $57^{\circ} \mathrm{C}$, and extension at $72^{\circ} \mathrm{C}, 10 \mathrm{~s}$. Quantitative evaluation of fluorescence signals from the PCR products was performed with the LightCycler software (version 3.5.) and was determined by plotting the fluorescence signals vs the cycle numbers at which the signals crossed the baseline. The baseline adjustment was performed in "minimize error" mode. Samples containing $10^{8}$ to $10^{2}$ cDNA molecules of the respective gene were included as external standards. The correlation coefficient among the standard reactions assured linearity.

\subsection{DNA isolation and PCR analysis}

For DNA extraction, each organ (brain, heart, kidney, liver, lungs, and spleen) was thawed in ten time-volume of extraction buffer (0.1 M Tris- $\mathrm{HCl}, \mathrm{pH} 9.0,1 \% \mathrm{SDS}, 0.1 \mathrm{M}$ $\mathrm{NaCl}, 1 \mathrm{mM}$ EDTA) and $20 \mathrm{mg} / \mathrm{ml}$ of proteinase $\mathrm{K}$ at $55^{\circ} \mathrm{C}$. DNA was purified by phenol-chloroform extraction and ethanol precipitated. DNA concentration was adjusted to $20 \mu \mathrm{g} / \mathrm{ml}$ for PCR. DNA of uninfected organs was prepared and used as a negative control and $N$. caninum tachyzoite DNA was prepared and used as a positive control. Specific $N$. caninum DNA was amplified by PCR by a modification of a previously described method (Liddell et al., 1999). Briefly, product amplification was performed with $1 \mu$ of template DNA, in a final volume of $10 \mu \mathrm{l}$ containing $1.5 \mathrm{mM} \mathrm{MgCl}_{2}$ (Roche Diagnostics, Peuzberg, Germany), $10 \mathrm{mM}$ Tris- $\mathrm{HCl}$, (pH 8.3), $50 \mathrm{mM} \mathrm{KCl}, 200 \mu \mathrm{M}$ of dNTPs (Invitek, Berlin), $0.5 \mu \mathrm{M}$ of each primer (forward primer Np21plus: 5'-CCC AGT GCG TCC AAT CCT GTA AC, reverse primer Np6plus: 5' - CTC GCC AGT CAA CCT ACG TCT TCT) (TIBMolbiol, Berlin, Germany) and $1 \mathrm{U}$ of DNA polymerase AmpliTaq (Roche Diagnostics). The PCR program run was as follows: (1) denaturation at $80^{\circ} \mathrm{C}, 1 \mathrm{~min}$ (2) amplification in 28 cycles (including denaturation $\left[94^{\circ} \mathrm{C}, 45 \mathrm{~s}\right.$ ], annealing [ $63{ }^{\circ} \mathrm{C}, 60 \mathrm{~s}$ ], and extension $\left[74^{\circ} \mathrm{C}, 90 \mathrm{~s}\right]$ ) (3) final extension $\left[74^{\circ} \mathrm{C}, 8 \mathrm{~min}\right.$ ] (4) cooling $4^{\circ} \mathrm{C}$. Amplifications were made in a MWG AG Biotech Thermal Cycler (Ebersberg, Germany). The PCR products were analysed by electrophoresis in agarose gels.

\subsection{Serum IFN- $\gamma$ measurements}

Serum IFN- $\gamma$ titres in NcT-inoculated mice and controls were quantified with the Quantikine ${ }^{\circledR}$ M Murine IFN- $\gamma$ ELISA kit (R \& D Systems) according to manufacturer's instructions.

\subsection{Statistical analysis}

For the analysis of survival curves the log rank test and $\mathrm{R}$ software were used. For PCR experiments the level of 
significance of the results was calculated by analysis of variance single factor using Microsoft Excel 2000 software.

\section{Results}

\subsection{Survival rate and clinical signs}

In order to assess the susceptibility to $N$. caninum infection, $\mathrm{ScCr}$ mice and fully immunocompetent $\mathrm{ScSn}$ mice, were inoculated i.p. with $5 \times 10^{5} \mathrm{NcT}$. As shown in Fig. 1 all NcT-challenged ScSn mice showed no apparent signs of disease and survived until the end of the experiment $(90$ days). The same observation was made in PBS-treated $\mathrm{ScCr}$ or $\mathrm{ScSn}$ mice controls (data not shown). In contrast, infected $\mathrm{ScCr}$ mice displayed rough hair coats and were reluctant to move by day 5 post-infection. At day 6 , all $\mathrm{ScCr}$ animals were inactive and showed pelvic limb weakness. On day 7 post-infection (p.i.) three animals were found dead and a fourth died on next day (Fig. 1). These results show that $\mathrm{ScCr}$ mice are highly susceptible to an i.p. challenge with NcT.

\subsection{Detection of parasite DNA by PCR}

The presence of $N$. caninum DNA in brain, heart, pancreas, lung, and liver of infected $\mathrm{ScSn}$ and $\mathrm{ScCr}$ mice was monitored by PCR analysis on a group of 4 mice sacrificed at day 7 p.i., when all $\mathrm{ScCr}$ animals already presented signs of terminal disease. In the infected $\mathrm{ScCr}$ mice $N$. caninum DNA was detected in all analyzed organs (Fig. 2). On the contrary, no $N$. caninum DNA was detected in any of the analyzed organ samples of $\mathrm{ScSn}$ mice at the same day (Fig. 2). These results suggest that in contrast to $\mathrm{ScCr}$ mice, $\mathrm{ScSn}$ mice were fully competent to control this parasitic infection.

\subsection{Histopathological and immunohistochemical analysis}

In order to determine the existence of lesions or the presence of parasites on organs of $\mathrm{ScCr}$ and $\mathrm{ScSn}$ mice at day 7 post-infection with $5 \times 10^{5} \mathrm{NcT}$, thin sections of brain,

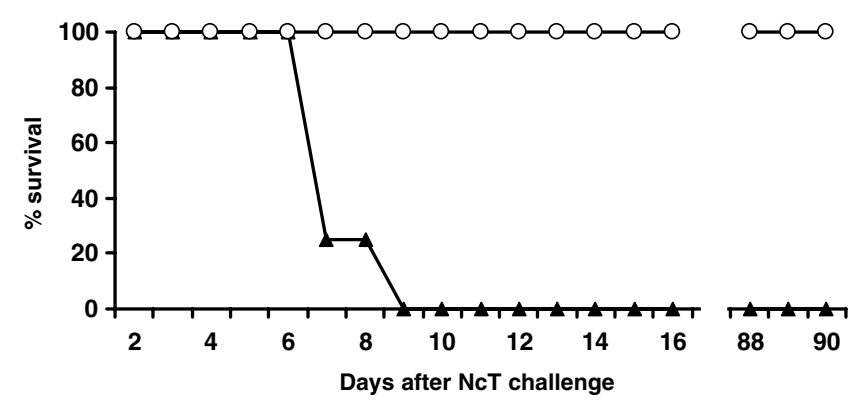

Fig. 1. High Susceptibility of $\mathrm{ScCr}$ mice to $N$. caninum infection. Survival rate of $\mathrm{ScSn}$ (open circles) or $\mathrm{ScCr}$ (closed triangles) mice inoculated i.p. with $5 \times 10^{5} \mathrm{NcT}$. The survival rate of $\mathrm{ScCr}$ mice was significantly different from that of $\mathrm{ScSn}$ mice (log Rank test, $\chi^{2}=7.6$ on 1 degrees of freedom, $p=0.00582$ ). Four mice per group were used. This is one representative result of two independent experiments.

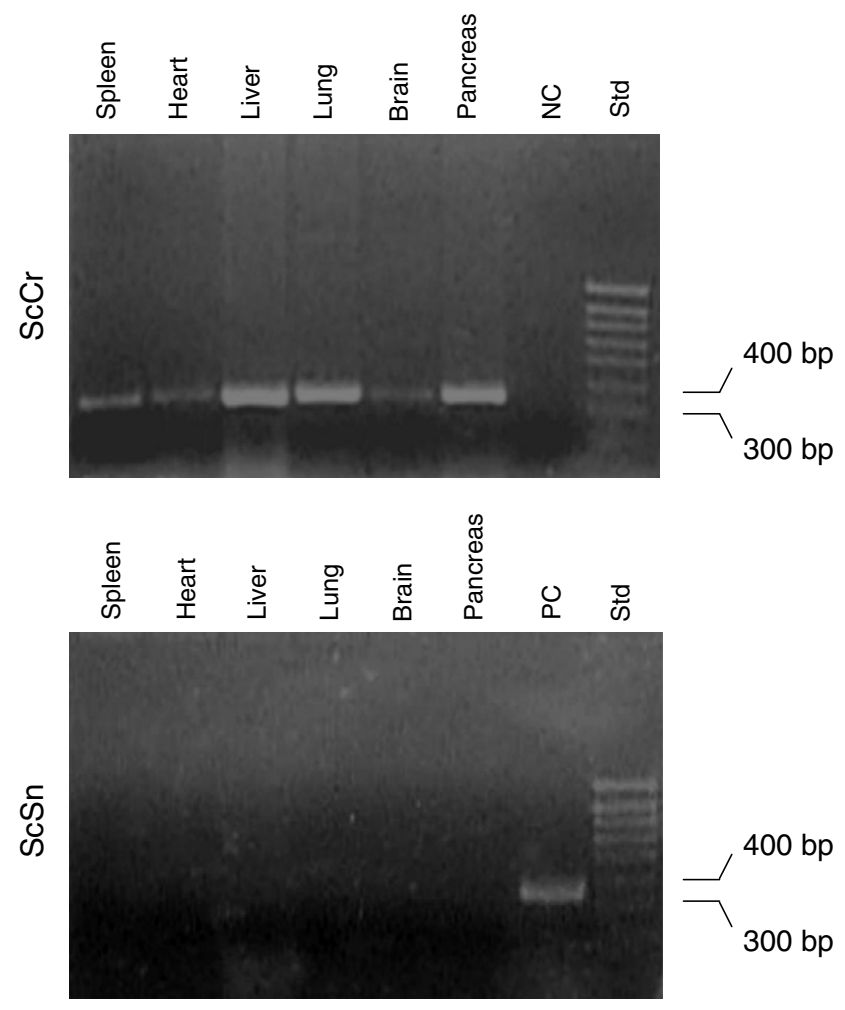

Fig. 2. Detection of parasite-specific DNA in NcT-challenged mice. Agarose gel electrophoresis of $N$. caninum-specific PCR products, of the expected band-size, amplified from DNA samples collected from the indicated organs of NcT-challenged ScCr and ScSn mice. Negative (NC) and positive (PC) control samples and DNA ladder standards (Std) were also shown. Results correspond to samples collected from one mouse of the indicated strains and are a representative example of two independent experiments performed with groups of four mice per strain.

heart, intestine, pancreas, lung, and liver were stained with HE or $N$. caninum-specific anti-serum for pathological and immunohistochemical analysis, respectively.

Results are summarized in Table 1. No lesions or parasites were observed on any organ of NcT-challenged $\mathrm{ScSn}$ mice. In contrast, the histopathological analysis of the infected $\mathrm{ScCr}$ mice showed lesions in the lung, pancreas, liver and intestine (Fig. 3). No lesions were detected in the heart and brain of these animals. All the livers of NcT-challenged mice presented a diffuse hepatitis with small necrotic areas (Fig. 3G) and tachyzoites scattered on the sinusoidal spaces (Fig. 3I). In 3 of 4 animals fibronecrotic perihepatitis was also present on the Glisson capsule (Fig. 3H). In pancreas of all infected animals, an extensive necrosis with neutrophilic, lymphocytic and plasma cells infiltration was present (Fig. 3D and E). These lesions were more conspicuous on the periphery of the organ. In these necrotic areas, small clusters of tachyzoites forming cyst-like structures were also observed (Fig. 3E). The same kind of lesions was present in adipose and connective tissue surrounding the pancreas. The lung of 3 of the 4 animals had large areas of atelectasis and pneumonia with neutrophils (Fig. 3A and B). In the remaining mouse, alveolar edema and hemorrhage was present. The small intestine of all animals showed an infiltration of neutrophils (Fig. 3K), necrosis 

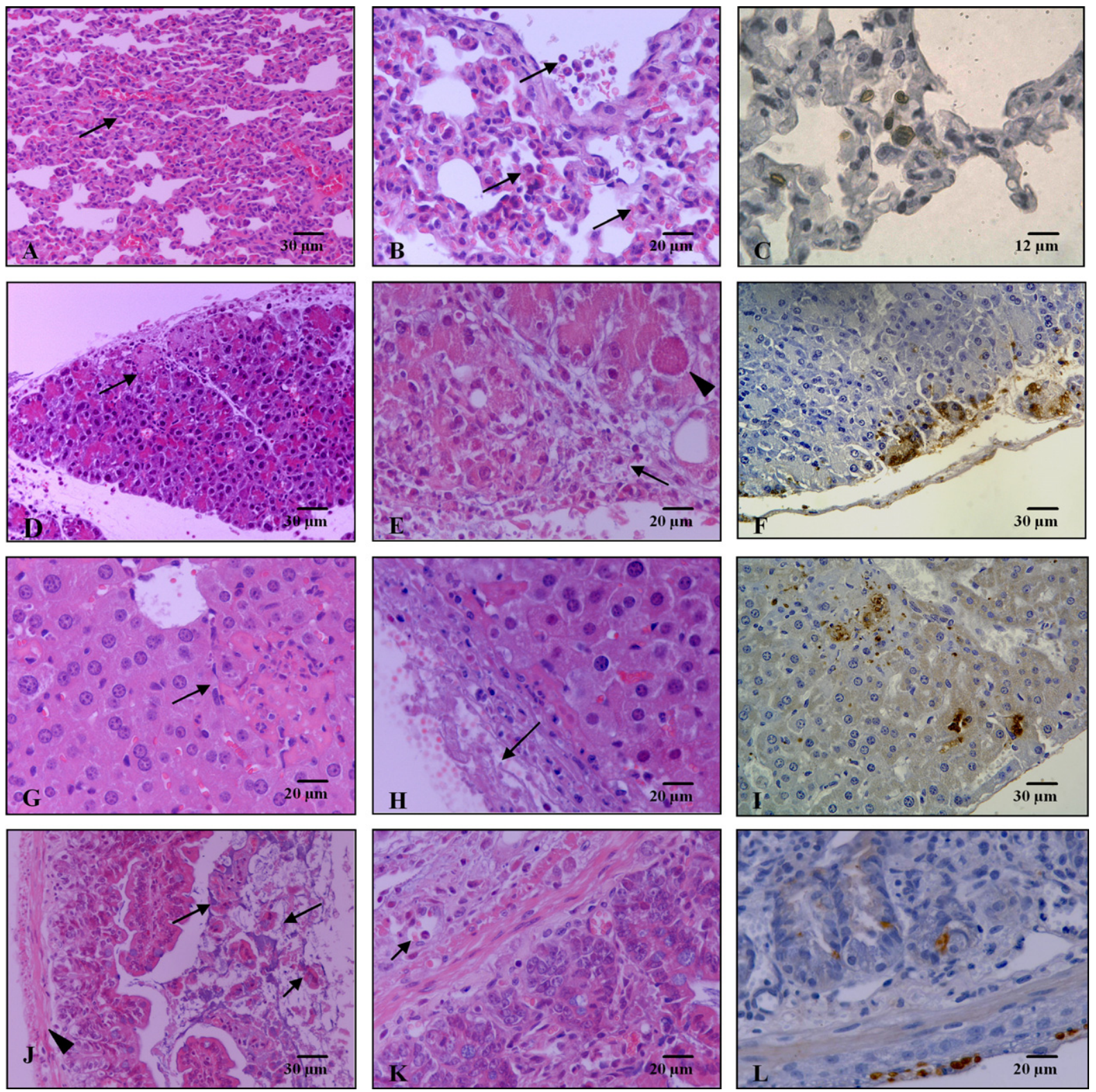

Fig. 3. Histopathology and immunohistochemistry analysis of $\mathrm{ScCr}$ mice organs on day 7 after infection with $5 \times 10^{5} \mathrm{NcT}$. Thin sections of lung (A-C), pancreas (D-F), liver (G-I), and intestine (J-L) of ScCr mice stained with haematoxylin-eosin or by immunohistochemistry with specific $N$. caninum antiserum and counterstained with haematoxilyn. The lung is characterized by atalectasic areas (A-arrow) and pneumonia with neutrophil infiltration (Barrow). In (C) tachyzoites inside macrophages are observed. In pancreas, an extensive necrotic area (D—arrow), cyst-like structures (E-arrowhead) and inflammatory infiltration (E-arrow) and several tachyzoites (F) are present, mostly in the periphery of the organ. The liver showed small necrotic areas (G-arrow) a fibrino-necrotic peri-hepatitis (H-arrow) and disseminated tachyzoites essentially in the periphery of the organ (I). In small intestine nesrosis and desquamation of the villi ( $\mathrm{J}$ - arrows) thick membrane of fibrino-necrotic inflammation on serosal surface ( $\mathrm{J}$ - arrowhead), infiltration of neutrophils (K-arrow) and tachyzoites in serosal surface and mucosa $(\mathrm{L})$ was present. This is one representative result of two independent experiments with four mice each.

and desquamation of the villi (Fig. 3J). On the serosal surface, a fibrino-necrotic inflammation was present forming a thick membrane (Fig. 3J). These lesions were also present in the large intestine but with lower intensity (data not shown).

By immunohistochemical analysis $N$. caninum was observed in three forms: free tachyzoites, aggregates of parasites in cyst-like structures and as an antigen in the cytoplasm of phagocytic cells. This study revealed no $N$. caninum forms in $\mathrm{ScSn}$ mice organs. In $\mathrm{ScCr}$ mice, the para- site was present in most of the analyzed tissues (Table 1). Brain and heart had only a small number of free tachyzoites or rare cyst-like structures. The lung presented a moderate number of tachyzoites mostly at alveolar capillaries (Fig. 3C) and in two animals, cyst-like structures and antigen inside phagocytic cells. The pancreas and liver were the most affected organs with the parasite present essentially in the periphery of the organ (Fig. $3 \mathrm{~F}$ and I). The small intestine presented a moderate number of tachyzoites mostly on the serosal surface but also on the mucosa (Fig. 3L). 


\subsection{Cytokine analysis}

Since the production of IFN- $\gamma$ and IL- 4 have been respectively associated with host resistance or susceptibility to neosporosis (Nishikawa et al., 2001; Baszler et al., 2000), the levels of mRNA coding for these cytokines were assessed in the spleen of $\mathrm{ScSn}$ and $\mathrm{ScCr}$ mice challenged with $N$. caninum. As shown in Fig. 4, spleen IL-4 mRNA levels were found to be higher in $\mathrm{ScCr}$ mice challenged with NcT than in respective PBS-treated controls or similarly challenged $\mathrm{ScSn}$ mice, 4 days after the i.p. inoculations. In NcT-infected ScSn mice, spleen IL-4 mRNA levels were not detected above those of PBS-treated controls. As also shown in Fig. 4, ScSn mice challenged with NcT had increased levels of mRNA for IFN- $\gamma$ as compared to PBStreated controls, detected on day 4 after challenge. The levels of mRNA for IFN- $\gamma$ detected in the spleen of $\mathrm{ScSn}$ mice at 2 and 4 days after i.p. challenge with NcT, were significantly increased as compared to those detected in similarly
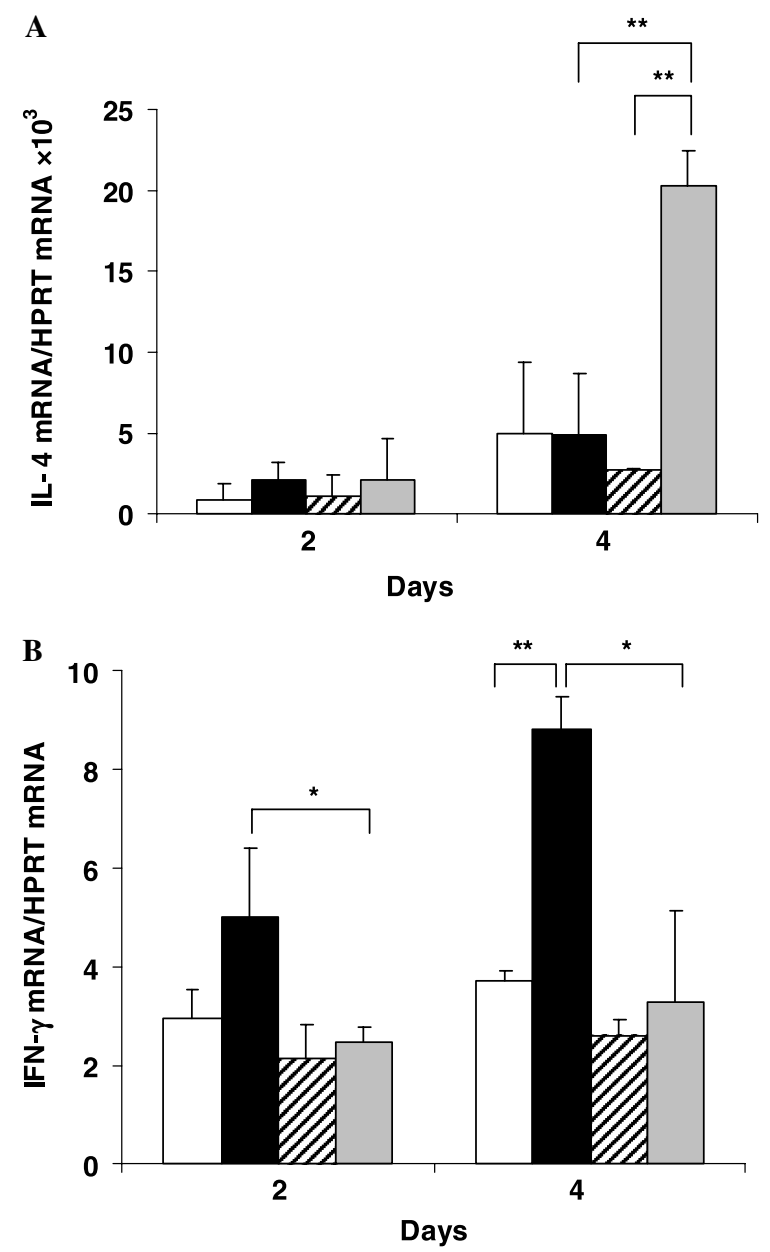

Fig. 4. Levels of IL-4 (A) or IFN- $\gamma$ (B) mRNA normalized to HPRT mRNA, detected by real-time PCR in the spleen of ScSn mice 2 or 4 days after challenge i.p. with PBS (open bars) or with $5 \times 10^{5} \mathrm{NcT}$ (closed bars) or in the same organ in $\mathrm{ScCr}$ mice treated i.p. with PBS (dashed bars) or with $5 \times 10^{5} \mathrm{NcT}$ (grey bars). Bars represent the mean plus one SD of three mice per control or NcT-infected groups. For each assessed cytokine, this is one representative result of two independent experiments. $\left({ }^{*} p<0.05 ; * * p<0.01\right)$.
Table 2

Concentration of IFN- $\gamma$, assessed by ELISA in the sera of $\mathrm{ScSn}$ or $\mathrm{ScCr}$ mice, 2 or 5 days after i.p. treatment with PBS or with $5 \times 10^{5} \mathrm{NcT}$, as indicated

\begin{tabular}{llll}
\hline Mice & Treatment & IFN- $\gamma$ pg/ml \\
\cline { 3 - 4 } & & Day 2 & Day 5 \\
\hline ScSn & PBS & $13 \pm 10^{1}$ & $3 \pm 3$ \\
& $5 \times 10^{5} \mathrm{NcT}$ & $592 \pm 11^{* *}(\mathrm{a}),{ }^{* *}(\mathrm{~b})$ & $784 \pm 55^{* *}(\mathrm{a}),{ }^{* *}(\mathrm{~b})$ \\
$\mathrm{ScCr}$ & $\mathrm{PBS}$ & $\mathrm{ND}$ & $\mathrm{ND}$ \\
& $5 \times 10^{5} \mathrm{NcT}$ & $\mathrm{ND}$ & $209 \pm 31^{* *}(\mathrm{a})$ \\
\hline
\end{tabular}

${ }^{1}$ Results represent the mean plus one SD of three mice per group. Statistically significant differences $\left(^{* *}, p<0.01\right)$ between NcT-challenged and PBS-treated mice on each strain (a) or between NcT-challenged mice in the two different strains (b), on the indicated days, were shown. ND, not detected; this is one representative result of two independent experiments.

challenged $\mathrm{ScCr}$ mice (Fig. 4). In NcT-infected $\mathrm{ScCr}$ mice, spleen IFN- $\gamma$ mRNA levels were not detected above those of PBS-treated controls. No differences on IFN- $\gamma$ or IL-4 mRNA levels were found among the different studied mice groups on day 1 after challenge (data not shown). In agreement with the increased spleen levels of IFN- $\gamma$ mRNA detected in NcT-challenged $\mathrm{ScSn}$ mice, comparatively to similarly challenged $\mathrm{ScCr}$ mice, serum levels of this cytokine were also found to be higher in $\mathrm{ScSn}$ than in $\mathrm{ScCr}$ mice, 2 or 5 days after challenge with NcT (Table 2). Interestingly, as shown in Table 2 , serum IFN- $\gamma$ was also detected on day 5 after the parasitic challenge in $\mathrm{ScCr}$ mice, although at lower levels than those detected in $\mathrm{ScCn}$ mice. Together, these results indicate that the higher susceptibility of $\mathrm{ScCr}$ mice to $N$. caninum infection results from their impaired capacity to mount a protective IFN- $\gamma$-mediated immune response, reinforcing the association of host production of this cytokine with resistance to neosporosis.

\section{Discussion}

In the present report, we show that $\mathrm{ScCr}$ mice are highly susceptible to an i.p. challenge with $\mathrm{NcT}$, developing lethal acute neosporosis. In contrast, $\mathrm{ScSn}$ mice were able to contain the infection when challenged with the same inoculum. This increased susceptibility of the $\mathrm{ScCr}$ mice comparatively to that of ScSn mice could be explained by either or both genetic defects carried by the $\mathrm{ScCr}$ strain: lack of the Tlr4 gene (Poltorak et al., 1998) and defective $I L-12 R \beta 2$ gene (Poltorak et al., 2001).

It was previously described that $\mathrm{ScCr}$ mice have an impaired IFN- $\gamma$-mediated response to protozoa (Freudenberg et al., 1991; Müller et al., 1997). This is in agreement with the results reported here that $\mathrm{ScCr}$ mice challenged i.p. with $N$. caninum did not show increased spleen levels of IFN- $\gamma$ mRNA, a key cytokine in host resistance to $N$. caninum (Nishikawa et al., 2001; Khan et al., 1997). In contrast, similarly challenged $\mathrm{ScSn}$ mice responded with increased IFN- $\gamma$ mRNA and were fully competent to resist the infection. This quantitative difference in the expression of IFN- $\gamma$ mRNA detected in the $N$. caninum-infected $\mathrm{ScCr}$, comparatively to $\mathrm{ScSn}$ mice, is in agreement with a similar pattern of 
IFN- $\gamma$ production reported to occur in the same mice strains upon infection with another Apicomplexa protozoan (Freudenberg et al., 1991). Moreover, increased levels of IL-4 mRNA were also detected in the spleen of $\mathrm{ScCr}$ mice comparatively to $\mathrm{ScSn}$ mice. This is in agreement with previous studies where production of this cytokine has been associated with host susceptibility to $N$. caninum infection (Baszler et al., 2000; Long and Baszler, 2000; Quinn et al., 2004).

The impaired immune response of $\mathrm{ScCr}$ mice to microbial infections has been explained by their inability to respond to IL-12 (Merlin et al., 2001). Taking into account previous reports where this cytokine has been shown to mediate protection to $N$. caninum infection in mice (Khan et al., 1997; Baszler et al., 1999) the high susceptibility of $\mathrm{ScCr}$ mice to neosporosis reported here, is in agreement with their lack of IL-12 responsiveness. IL-12 is a well known inducer of IFN- $\gamma$ production and favours the differentiation of Th1 cells (Trinchieri, 2003). In addition, IL-12 has also been shown to directly contribute for in vitro proliferation, expression of CD25 (and IFN $-\gamma$ mRNA) by $\mathrm{CD} 4^{+} \mathrm{CD} 25^{-} \mathrm{T}$ cells, even in the presence of $\mathrm{T}$ regulatory cells (King and Segal, 2005). Therefore, considering these activities of IL-12, it could be hypothesized that lack of a functional IL-12R could impair the activation of effector T cells in the NcT-challenged ScCr mice. Also IL-12 has been recently shown to increase IFN- $\gamma$ production by IL- 2 activated bovine NK cells in response to NcT (Boysen et al., 2006) and a similar host-protective mechanism, necessarily absent in the $\mathrm{ScCr}$ mice, can also be relevant for resistance to murine $N$. caninum infection. Production of IFN- $\gamma$ by mechanisms independent of IL-12 has been described (Freundenberg et al., 2002). This could explain the detection of the former cytokine in the serum of $\mathrm{ScCr}$ mice, however at lower levels and later than in ScSn mice. However, taking into account the lethal susceptibility to $N$. caninum of $\mathrm{ScCr}$ mice, this later and lower IFN- $\gamma$ production is not enough to confer protection against this parasite. This could indicate that protective immune mechanisms effective to prevent NcT infection must be elicited early after the infectious challenge.

$\mathrm{ScCr}$ mice also fail to express TLR4 (Poltorak et al., 1998; Poltorak et al., 2000). Therefore, their increased susceptibility to $N$. caninum could also be contributed for by this particular deficiency. This pattern recognition receptor has been shown to be relevant for the host immune defence against the protozoa Leishmania major (Kropf et al., 2004) and Trypanosoma cruzi (Oliveira et al., 2004). Also surface lipopeptidophosphoglycan of Entamoeba hystolytica was shown to induce the release of pro-inflammatory mediators by human macrophages (MaldonadoBernal et al., 2005). However, signalling via TLR4 of heat shock protein 70 from the $N$. caninum closely related protozoan $T$. gondii has been implicated in mechanisms of controlling excessive inflammation triggered by this parasite (Mun et al., 2005). Further studies to be done in mice deficient in TLR4 in the absence of other genetic defects will thus be necessary in order to determine whether this receptor plays a significant role in the course of $N$. caninum infection. In particular it would be interesting to determine in what measure the lack of TLR4 expression contributes to the severe pathology observed in the NcT-challenged $\mathrm{ScCr}$ mice.

The $\mathrm{ScCr}$ mice could thus be useful for subsequent studies on the immunobiology of $N$. caninum infection and constitute an alternative model to mice bearing more severe immunodeficiencies.

\section{Acknowledgments}

The authors are indebted to Dr. Nuno Sepulveda for help with statistical analysis. We would also like to acknowledge Fátima Faria, for her excellent technical assistance in the immunohistochemistry procedures. This work was supported by Fundação para a Ciência e a Tecnologia (FCT), Grant No. POCTI/CVT/38791/MGI/2001 and FEDER. Luzia Teixeira is financed by FCT fellowship SFRH/BD/12983/2003.

\section{References}

Baszler, T.V., Long, M.T., McElwain, T.F., Mathison, B.A., 1999. Interferon- $\gamma$ and interleukin-12 mediate protection to acute Neospora caninum infection in BALB/c mice. International Journal for Parasitology 29, 1635-1646.

Baszler, T.V., McElwain, T.F., Mathison, B.A., 2000. Immunization of BALB/c mice with killed Neospora caninum tachyzoite antigen induces a type 2 immune response and exacerbates encephalitis and neurological disease. Clinical and Diagnostic Laboratory Immunology 7, 893-898.

Bjerkås, I., Mohn, S.F., Presthus, J., 1984. Unidentified cyst-forming sporozoan causing encephalomyelitis and myositis in dogs. Zeitschrift fur Parasitenkunde 70, 271-274.

Boysen, P., Klevar, S., Olsen, I., Storset, A.K., 2006. The protozoan Neospora caninum directly triggers bovine NK cells to produce gamma interferon and to kill infected fibroblasts. Infection and Immunity 74, 953-960.

Dreier, K.J., Stewarter, L.W., Kerlin, R.L., Ritter, D.M., Brake, D.A., 1999 Phenotypic characterisation of a Neospora caninum temperature-sensitive strain in normal and immunodeficient mice. International Journal for Parasitology 29, 1627-1634.

Dubey, J.P., Hattel, A.L., Lindsay, D.S., Topper, M.J., 1988. Neonatal Neospora caninum infection in dogs: isolation of the causative agent and experimental transmission. Journal of the American Veterinary Medical Association 193, 1259-1263.

Dubey, J.P., Lindsay, D.S., 1996. A review of Neospora caninum and neosporosis. Veterinary Parasitology 67, 1-59.

Dubey, J.P., Lindsay, D.S., 2000. Gerbils (Meriones unguiculatus) are highly susceptible to oral infection with Neospora caninum oocysts. Parasitology Research 86, 165-168.

Dubey, J.P., 2003. Review of Neospora caninum and neosporosis in animals. Korean Journal of Parasitology 41, 1-16.

Freudenberg, M.A., Kumazawa, Y., Meding, S., Langhorne, J., Galanos, C., 1991. Gamma interferon production in endotoxin-responder and -nonresponder mice during infection. Infection and Immunity 59, 3484-3491.

Freundenberg, M.A., Merlin, T., Kalis, C., Chvatchko, Y., Stübig, H., Galanos, C., 2002. Cutting edge: a murine, IL-12-independent pathway of IFN- $\gamma$ induction by gram-negative bacteria based on STAT4 activation by type I IFN and IL-18 signalling. The Journal of Immunology $169,1665-1668$. 
Haddad, J.P.A., Dohoo, I.R., VanLeewen, J.A., 2005. A review of Neospora caninum in dairy and beef cattle - a Canadian perspective. The Canadian Veterinary Journal 46, 230-243.

Hemphill, A., 1996. Subcellular localization and functional characterization of Nc-p43, a major Neospora caninum tachyzoite surface protein. Infection and Immunity 64, 4279-4287.

Hsu, S.M., Raine, L., Fanger, H., 1981. The use of antividin antibody and avidin-biotin-peroxidase complex in immunoperoxidase techniques. American Journal of Clinical Pathology 75, 816-821.

Innes, E.A., Wright, S., Bartley, P., Maley, S., Macaldowie, C., EstebanRedondo, I., Buxton, D., 2005. The host-parasite relationship in bovine neosporosis. Veterinary Immunology and Immunopathology 108, 29-36.

Khan, I.A., Schwartzman, J.D., Fonseka, S., Kasper, L.H., 1997. Neospora caninum: role for immune cytokines in host immunity. Experimental Parasitology 85, 24-34.

King, I.L., Segal, B.M., 2005. Cutting edge: IL-12 induces $\mathrm{CD} 4{ }^{+} \mathrm{CD} 25^{-} \mathrm{T}$ cell activation in the presence of $\mathrm{T}$ regulatory cells. The Journal of Immunology 175, 641-645.

Kropf, P., Freundenberg, M.A., Modolell, M., Price, H.P., Herath, S., Antoniazi, S., Galanos, C., Smith, D.F., Müller, I., 2004. Toll-like receptor 4 contributes to efficient control of infection with the protozoan parasite Leishmania major. Infection and Immunity 72, 1920-1928.

Liddell, S., Jenkins, M.C., Dubey, J.P., 1999. A competitive PCR assay for quantitative detection of Neospora caninum. International Journal for Parasitology 29, 1583-1587.

Lindsay, D.S., Dubey, J.P., 1989a. Immunohistochemical diagnosis of Neospora caninum in tissue sections. American Journal of Veterinary Research 50, 1981-1983.

Lindsay, D.S., Dubey, J.P., 1989b. Neospora caninum (Protozoa: apicomplexa) infections in mice. The Journal of Parasitology 75, 772-779.

Long, M.T., Baszler, T.V., 2000. Neutralization of maternal IL-4 modulates congenital protozoal transmission: comparison of innate versus acquired immune responses. The Journal of Immunology 164, $4768-4774$.

Maldonado-Bernal, C., Kirschning, C.J., Rosenstein, Y., Rocha, L.M., Rios-Sarabia, N., Espinosa-Cantellano, M., Becker, I., Estrada, I., Salazar-González, R.M., López-Macias, C., Wagner, H., Sánchez, J., Isibasi, A., 2005. The innate immune response to Entamoeba hystolitica lipopeptidophosphoglycan is mediated by toll-like receptors 2 and 4. Parasite Immunology 27, 127-137.

Merlin, T., Sing, A., Nielsen, P.J., Chris, G., Freudenberg, M.A., 2001. Inherited IL-12 unresponsiveness contributes to the high LPS resis- tance of the LPS ${ }^{d}$ C57BL/10ScCr mouse. The Journal of Immunology 166, 566-573.

Müller, I., Freudenberg, M., Kropf, P., Kiderlen, A.F., Galanos, C., 1997. Leishmania major infection in C57BL/10 mice differing at the Lps locus: a new non-healing phenotype. Medical Microbiology and Immunology 186, 75-81.

Mun, H.S., Aosai, F., Norose, K., Piao, L.X., Fang, H., Akira, S., Yano, A., 2005. Toll-like receptor 4 mediates tolerance in macrophages stimulated with Toxoplasma gondii-derived heat shock protein 70 . Infection and Immunity 73, 4634-4642.

Nishikawa, Y., Tragoolpua, K., Inoue, N., Makala, L., Nagasawa, H., Otsuka, H., Mikami, T., 2001. In the absence of endogenous gamma interferon, mice acutely infected with Neospora caninum succumb to a lethal immune response characterized by inactivation of peritoneal macrophages. Clinical and Diagnostic Laboratory Immunology 8, $811-816$.

Oliveira, A.C., Peixoto, J.R., de Arruda, L.B., Campos, M.A., Gazzinelli, R.T., Golenbock, D.T., Akira, S., Previato, J.O., Mendonça-Previato, L., Nobrega, A., Bellio, M., 2004. Expression of functional TLR4 confers pro-inflammatory responsiveness to Trypanosoma cruzi glycoinositolphospholipids and higher resistance to infection with $T$. cruzi. The Journal of Immunology 173, 5688-5696.

Poltorak, A., He, X., Smirnova, I., Liu, M.Y., Huffel, C.V., Du, X., Birdwell, D., Alejos, E., Silva, M., Galanos, C., Freuderberg, M., RicciardiCastagnoli, P., Layton, B., Beutler, B., 1998. Defective LPS signaling in $\mathrm{C} 3 \mathrm{H} / \mathrm{HeJ}$ and $\mathrm{C} 57 \mathrm{BL} / 10 \mathrm{ScCr}$ mice: mutations in Tlr4 gene. Science 282, 2085-2088.

Poltorak, A., Merlin, T., Nielsen, P.J., Sandra, S., Smirnova, I., Schupp, I., Boehm, T., Galanos, C., Freudenberg, M.A., 2001. A point mutation in the $I L-12 R \beta 2$ gene underlies the IL-12 unresponsiveness of $L p s$-defective C57BL/10ScCr mice. The Journal of Immunology 167, 2106-2111.

Poltorak, A., Smirnova, I., Clisch, R., Bruce, B., 2000. Limits of a deletion spanning Tlr4 in C57BL/10ScCr mice. Journal of Endotoxin Research 6, 51-56.

Quinn, H.E., Miller, C.M., Ellis, J.T., 2004. The cell-mediated immune response to Neospora caninum during pregnancy in the mouse is associated with a bias towards production of interleukin-4. International Journal for Parasitology 34, 723-732.

Sawada, M., Park, C.H., Morita, T., Shimada, A., Umemura, T., Haritani, M., 1997. Pathological findings of nude mice inoculated with bovine Neospora. The Journal of Veterinary Medical Science 59, 947-948.

Trinchieri, G., 2003. Interleukin-12 and the regulation of innate resistance and adaptive immunity. Nature Reviews. Immunology 3, 133-146. 